\title{
Assessment of training for creating awareness on certification mark among rural people
}

\author{
SERENE SHEKHAR, SHRIDHAR D. JOSHI AND M.K. CHAUDHARY
}

See end of the paper for authors' affiliations

\section{SERENE SHEKHAR}

Department of Extension and Communication Management,

Sardarkrushinagar Dantiwada

Agricultural University, S.K. NAGAR (GUJARAT) INDIA

Email : shekhar.sdau@gmail.com

Received: 12.04.2017; Revised: 30.09.2017; Accepted: 16.10.2017

ABSTRACT : The study was undertaken in Banaskantha district, under AGRESCO Project, Sardarkrushinagar Dantiwada Agricultural University of Gujarat state; to assess and compare training outcomes on enhancing awareness among respondents regarding certification marks. Randomly selected 160 respondents were considered as sample for the study. Half of the respondents were beneficiary of the training programme and the other half was control group. A pre-structured interview scheduled was used to measure independent variables and dependent variables. Frequency, percentage, range and chi-square test were used to tabulate the data. The findings revealed that cent per cent of the training beneficiary were able to identify ISI mark, toxicity mark and vegetarian mark. When compared between training beneficiary and nonbeneficiary the result was found to be highly significant $\left(\mathrm{z}=30.0986^{* *}\right)$. The findings also revealed that cent per cent of the beneficiary were able to associate product with vegetarian mark and toxicity mark, followed by 90 per cent were able to associate BIS Hallmark, 87.5 per cent were able to associate ISI mark with the product. When compared between beneficiary and non-beneficiary, the result was found to be highly significant $\left(\mathrm{z}=24.9128^{* *}\right)$. It can be concluded from the study that awareness generating programme on certification mark could be beneficial for the rural people.

KEY WORDS: Certification marks, Awareness, Training, Rural

- HOW TO CITE THIS PAPER : Shekhar, Serene, Joshi, Shridhar D. and Chaudhary, M.K. (2017). Assessment of training for creating awareness on certification mark among rural people. Asian J. Home Sci., 12 (2) : 408-414, DOI: 10.15740/HAS/AJHS/12.2/408-414. 